\title{
ANALISA PREDIKTIF CURAH HUJAN DATA TIME SERIES BERBASIS METODE NEURAL NETWORK
}

\author{
Sitti Harlina ${ }^{1}$, Usman $^{2}$ \\ Teknik Informatika,STMIK Dipanegara Makassar ${ }^{1,2}$ \\ Email : sitiharlina76@gmail.com¹, usman@dipanegara.ac.id ${ }^{2}$
}

\begin{abstract}
ABSTRAK
Hujan merupakan fenomena alam yang selalu dijumpai dalam kehidupan sehari - hari, perubahan pola curah hujan yang berbeda- beda sangat berpengaruh terhadap aspek kehidupan terutama di Kota Makassar, dimana aktivitas penting berada didalamnya, sehingga perlu dilakukan analisa prediksi curah hujan guna memberikan manfaat buat masyarkat dalam hal pelayaran, pertanian, pentuan pola tanam dan mitigasi bencana. Penelitian ini akan menganalisa prediksi curah hujan dengan cara menganalisa pola rentet waktu yang berubah - ubah dari data set curah hujan yang diambil dari Stasiun Romang Polong Makassar dari tahun 2005-2015, yang memudahkan dalam proses analisa prediksi akurasi yang dihasilkan dari pola rentet waktu data set tersebut, jika diterapkan dengan metode Neural Network (NN). Penelitian ini mengambil data curah hujan sebagai tahap awal data mining, yang meliputi proses input data ke format yang dibutuhkan, pengelompokan dan penentuan atribut data serta pemecahan data (split) untuk digunakan dalam proses pembelajaran (training) dan pengujian (testing). Tahap pengolahan data awal (preprocessing) dengan data set dari variable curah hujan memiliki 120 record.Hasil dari penelitian ini menunjukkan model terbaik dari Neural Network (NN) diperoleh model terbaik input layer 30, hidden layer 17, training cycle 500 , learning rate 0.1 dan momentum 0,2 setelah proses iterasi ke 500 maka nilai RMSE terkecil 0.126 - 0.027 (mikro:0,129+/-0,000). Hal ini menunjukkan metode Neural Network bisa diterapkan walaupun dengan tingkat kelayakan belum dipastikan maksimal.
\end{abstract}

Kata Kunci : Analisis, Curah Hujan, Neural Network, Prediktif, Time Series

\begin{abstract}
Different rainfall patterns greatly affect aspects of life, especially in Makassar City, where important activities are located, so it is necessary to analyze rainfall predictions to provide benefits to the community in terms of shipping, agriculture, determining planting patterns and disaster mitigation. This research will analyze the prediction of rainfall by analyzing the time series pattern which changes from the rainfall data set taken from Romang Polong Makassar Station from 2005-2015, which facilitates the process of analyzing the accuracy prediction generated from the time series data set pattern. if applied with the Neural Network (NN) method. This study takes rainfall data as the initial stage of data mining, which includes the process of inputting data into the required format, grouping and determining data attributes and splitting data for use in the learning process (training) and testing (testing). The initial data processing stage (preprocessing) with data sets from variable rainfall has 120 records. The results of this study show that the best model from the Neural Network (NN)
\end{abstract}


is obtained the best model input layer 30, hidden layer 17, training cycle 500, learning rate 0.1 and momentum 0.2 after the 500th iteration process, the smallest RMSE value is 0.126 0.027 (micro: $0.129+$ +/-0.000). This shows that the Neural Network method can be applied even though the maximum feasibility level has not been determined.

Keywords: Analysis, rainfall, Neural Network, Predictive, Time Series

\section{PENDAHULUAN}

Hujan merupakan fenomena alam yang selalu dijumpai dalam kehidupan sehari - hari, besarnya intensitas curah hujan berbeda-beda tergantung dari lamanya curah hujan dan frekuensi kejadiannya. Intensitas curah hujan yang tinggi pada umumnya berlangsung dengan durasi pendek dan meliputi daerah yang tidak luas, jarang sekali dengan intensitas tinggi, tetapi dapat berlangsung dengan durasi cukup panjang.

Intensitas curah hujan di kota Makassar juga kepadatannya tidak merata antara satu

tempat dengan tempat lain. Dalam penelitian ini akan membahas mengenai data curah hujan di kota Makassar. Data curah hujan sangat menarik untuk dikaji sebab curah hujan merupakan salah satu faktor terbesar yang mempengaruhi iklim suatu wilayah dan mempengaruhi berbagai sektor kehidupan manusia, diantaranya sektor pertanian, pelayaran, perkebunan, penerbangan, penentuan jenis pola tanam dimusim hujan dan musim kemarau serta penanggulangan mitigasi bencana alam.

Hujan yang terjadi di daerah tropis seperti di Indonesia, umumnya adalah hujan konvektif, hujan konvektif adalah tipe hujan yang terbentuk oleh adanya perbedaan panas yang diterima permukaan tanah dengan panas yang diterima oleh lapisan udara diatas permukaan tanah tersebut. Hal ini biasanya terjadi pada akhir musim kering dengan intensitas hujan yang tinggi, sebagai hasil proses kondensasi massa air basah pada ketinggian diatas $15 \mathrm{~km}$. Data curah hujan sangat menarik untuk dikaji sebab curah hujan merupakan salah satu faktor terbesar yang mempengaruhi iklim suatu wilayah dan mempengaruhi berbagai sektor kehidupan manusia. Kajian Data Mining dan ekonomi menunjukkan bahwa metode tersebut cocok untuk dipakai mengingat Neural Network (NN) dengan tingkat nilai error yang cukup rendah, kemampuan Neural Network dalam Universal Approximation telah diteliti oleh berbagai peneliti untuk peramalan data time series pada berbagai jenis data, sehingga kinerja dari Neural Network yang memuaskan dalam peramalan data time series, untuk menentukan model terbaik dari setiap periode sebelumnya di perlukan optimasi bobot dari setiap variabel data training yang relevan, sehingga metode Neural Network bisa diterapkan walaupun dengan tingkat kelayakan belum dipastikan maksimal.

Penelitian yang dilakukan oleh (Gema Indah Merdekawati, et.al.2019) yang memprediksi Curah hujan di Jakarta berbasis Algoritma Levenberg Marquardt dengan prediksi curah hujan di Jakarta menggunakan pola 23-14-1 dan 
dipengaruhi oleh oleh I parameter yaitu hidden layer. Data curah hujan yang digunakan dengan data curah hujan bulanan dari 1 mei 2016 - 30 April 2018.

Secara umum dan garis besar, Neural Network memiliki beberapa kelebihan atau keunggulan pada prediksi non linear, kuat di paralel processing dan kemampuan untuk montoleransi kesalahan (Y.H.Zweiri,

J.F.Whildborne,2013), melihat fenomena alam yang dalam hal ini curah hujan yang tinggi sering sekali menimbulkan berbagai bencana alam yang kadang mitigasi bencana berupa akibat yang ditimbulkan terlambat diantisipasi sehingga biaya, waktu dan tenaga yang dibutuhkan akan lebih besar setelah kejadian itu terjadi, diperlukan cara untuk memprakirakan banyaknya curah hujan dalam beberapa bulan kedepan, guna mengantisipasi kejadian yang tidak diinginkan. Penekanan biaya juga dapat dilakukan dengan cara menganalisa pola rentet waktu yang berubah - ubah dari data set curah hujan yang memudahkan dalam proses analisa prediksi akurasi jika diterapkan dengan metode Neural Network $(\mathrm{NN})$

Dari uraian di atas, akan dilakukan bagaimana analisa prediksi akurasi yang dihasilkan dari pola rentet waktu data set tersebut, jika diterapkan dengan metode Neural Network (NN)

Penelitian ini memiliki tujuan utama yaitu untuk mendapatkan akurasi yang dihasilkan dari metode Neural Network $(N N)$ yang diterapkan dan untuk mengetahui pola yang dihasilkan dari data set tersebut dengan melihat nilai RMSE terkecil

\section{LANDASAN TEORI}

Beberapa jurnal tentang curah hujan metode Neural Network (NN) antara lain, oleh(Pritpal Singh,2015) dalam Applications of Soft Computing in Time Series Forecasting, Series editor Janusz Kacprzyk], pada akademi polisi sains, Warsawa, Polandia, sebagai penerapan teknologi informasi berkembang sangat pesat, data dalam berbagai format juga telah menjamur dari waktu ke waktu. Salah satu kategori data seperti waktu data series. Serangkaian waktu adalah urutan nilai numerik yang tercatat selama periode, diukur biasanya pada titik-titik yang berurutan dalam waktu, biasanya berjarak pada kesamaan interval harian, mingguan, kuartalan, bulanan atau tahunan. Sebagai contoh, supermarket menyimpan angka harian penjualan, Badan Meteorologi mempunyai rekaman maksimum seharihari tentang curah hujan dan suhu minimum.

Analisis time series adalah alat penting untuk peramalan masa depan atas dasar sejarah masa lalu (Mehdi Mahnam dan Ghomi, 2012) Peramalan adalah bantuan yang penting untuk membuat keputusan dan merencanakan untuk manajemen yang efektif dari organisasi modern. Time series dianalisis untuk menemukan pola dan seri ini kemudian diekstrapolasi ke masa depan berdasarkan pola. Mencari tahu pola dan ekstrapolasi peristiwa masa depan berdasarkan pada pola merupakan subyek utama analisis time series. Metode tersebut umumnya digunakan ketika banyak informasi tentang proses generasi variabel diperkirakan tidak tersedia dan ketika variabel lainnya juga tidak memberikan penjelasan yang jelas tentang variabel yang diteliti. Time-series 
peramalan adalah bidang yang berkembang dan memainkan peran penting dalam banyak bidang praktis seperti ekonomi, keuangan, pemasaran, perencanaan, meteorologi dan telekomunikasi. Banyak teknik untuk peramalan time series. Sebuah tinjauan literatur pada time series forecasting dapat ditemukan di artikel yang ditulis oleh Gooijer dan Hyndman (Gooijer dan Hyndman 2006).

Aplikasi Prediksi Curah Hujan, Debit Air, dan kejadian Banjir Berbasis Web dengan Machine Learning di Deli Serdang merupakan penelitian yang memprediksi kejadian banjir dengan metode Artificial Neural Network (ANN) Backpropagation (BP-NN) dengan data set 1 januari 2016 - 31 Desember 2017, dari curah ujan dan debit air dengan akurasi yang cukup baik dengan kombinasi aplikasi Web sehingga mudah diakses (PHP) Hpertext Preprocessor, dengan menggunakan tiga stasiun yakni stasiun Klimatologi Sampali, Tuntungan, kualanamu ( Ikke Fitriyaningsih, 2018), sedangkan model yang terakhir didasarkan pada pendekatan pemodelan Jaringan Syaraf Tiruan (JST). (Alven Safik Ritonga,2015) menggunakan data curah, temperatur, kecepatan angin, penyinaran matahari dan kelembaban udara yang diambil dari Balai Informasi Sumber Daya Air (BISDA) Dinas PU NTB selama 31 tahun terakhir yakni dari tahun 1983-2014. Data ini di gunakan dalammemprediksi data hidrologi dan klimatologi pada tahun 2014. Dari hasil prediksi ditentukan kebutuhan air konsumtif tanaman (evapotranspirasi), curah hujan efektif dan kebutuhan air penyiapan lahan, kemudian dihubungkan dengan ketersediaan volume air irigasi dan lama tanam tanaman pangan untuk mendapatkan pola rancangan tanam berdasarkan pola tanam optimal dengan jadwal tanam setiap jenis tanaman pangan pada tahun 2014.

Analisis time series adalah alat penting untuk peramalan masa depan atas dasar sejarah masa lalu (Mahnam dan Ghomi, 2012). Peramalan adalah bantuan yang penting untuk membuat keputusan dan merencanakan untuk manajemen yang efektif dari organisasi modern. Time series dianalisis untuk menemukan pola dan seri ini kemudian diekstrapolasi ke masa depan berdasarkan pola. Mencari tahu pola dan ekstrapolasi peristiwa masa depan berdasarkan pada pola merupakan subyek utama analisis time series. Metode tersebut umumnya digunakan ketika banyak informasi tentang proses generasi variabel diperkirakan tidak tersedia dan ketika variabel lainnya juga tidak memberikan penjelasan yang jelas tentang variabel yang diteliti. Time-series peramalan adalah bidang yang berkembang dan memainkan peran penting dalam banyak bidang praktis seperti ekonomi, keuangan, pemasaran, perencanaan, meteorologi dan telekomunikasi. Banyak teknik untuk peramalan time series. Sebuah tinjauan literatur pada time series forecasting dapat ditemukan di artikel yang ditulis oleh Gooijer dan Hyndman (Gooijer dan Hyndman, 2006). Forecasting methods time series umumnya jatuh ke dalam dua kelompok: metode klasik, yang didasarkan pada statistik /konsep-konsep matematika, dan metode heuristik modern, yang didasarkan pada algoritma dari bidang soft computasi (SC). Untuk tujuan ini, berbagai metodologi soft computasi (SC) seperti himpunan fuzzy, ANN (Artificial Neural 
Network),RS (Rough Set) dan EC (Evolutionary Computing) dipelajari, dan ditemukan bahwa himpunan fuzzy metodologi banyak digunakan teknik dalam domain ini. Penerapan himpunan fuzzy dalam waktu peramalan sering disebut sebagai Fuzzy Time Series (FTS). Pendekatan pemodelan dan hibridisasi dengan konsep SC lainnya, sedangkan model yang terakhir didasarkan pada pendekatan pemodelan Jaringan Syaraf Tiruan (JST).

Penelitian oleh (Defanto Hanif Yornada, dkk, 2018) menggunakan data curah dalam memprediksi intesnitas curah hujan dengan menggunakan metode jaringan syaraf tiruan Backpropagation Penelitian ini merupakan upaya untuk mencari model data time series dengan data intensitas curah hujan bulanan di kabupaten Ponorogo. Hasil terbaik dari penelitian ini yaitu MAPE pengujian sebesar 20,28\% yang didapatkan dari stasiun penkar hujan Balong. Proses pelatihan menggunakan 10 neuron pada input layer, data latih dari tahun 1997 hingga 2015, data uji tahun 2016, 40 neuron oada hidden layer, batas MAPE sebesar 20\%, dan maksimum literasi 200000. Hasil yang didapatkan belum maksimal dan terlalu tinggi ini dikarenakan kondisi data yang terdapat banyak nilai 0 didalamnya.

Penelitian oleh (Purwanto, 2015) Pomodelan Prediktif Curah Hujan Univariate dan Mutivariate Pada Daerah Rawan Longsor di Kecamatan Banjarnegara dengan metode Neural Network hasil RMSEnya adalah 6.628843036. Data set multivarian RMSEnya lebih besar (16.762) karena belum diadakan seleksi atribut.
Penelitian oleh (I.M.Sofian dan Y.Apriani, 2017), yang bertujuan untuk memprediksi curah hujan bulanan dengan menggunakan jaringan syaraf tiruan (JST) backpropagatioan dengan mempergunakan data set curah hujan dari tahun 2014 - 2016 pada Stasiun Klimatologi Kelas I Palembang, Tahapan yang dilakukan dengan menganalisa tingkat korelasi antara output jaringan dengan data observasi dan data dari nilai MSE yang dihasilkan jaringan.Hasil dari penelitian ini menunjukkan jaringan terbaik pada jumlah neuron 12 pada lapisan input, hidden layer 3 pada 50-2020 neuron, 1 neuron pada lapisan output, nilai MSE0,00086145 (proses pelatihan) dan MSE 0,25528 korelasi pengujian.

Penelitian tentang curah hujan dengan kombinasi metode Jaringan Saraf Tiruan (Nurul Hidayat,2015), dalam Rainfall Forecasts in The City Of Mataram In The Year 2015 and 2016 Using Time Delay Neural Network Method, dengan hasil curah hujan tertinggi terjadi di bulan Februari, dan curah hujan terendah pada bulan juni ditahun 2015. Penelitian ANN (Syaefuddin Suhaedi, 2017), digunakan untuk memprediksi pola siklus data hidroklimatologi tahun akan datang dengan melihat pola tanam optimal agar tanaman terhindar dari gagal panen (puso). Jaringan Syaraf Tiruan untuk memprediksi curah hujan (Marihot Tp.Manalu), memprediksi curah hujan dengan software matlab metode backpropagation dan Penelitian JST Backpropagation dalam prediksi curah hujan (Ulviyana Cahyati, 2019), menghasilkan konversi jenis tanaman yang cocok ditanam dibulan bulan tertentu dan prediksi curah hujan dengan menggunakan algoritma Levenberg-Marquardt dan 
Backpropagation (NolavRitha,dkk, 2016), dengan hasil algoritma LevenbergMarquardt menghasilkan prediksi curah hujanyang lebih baik, di banding dengan Algoritma Backpropagation.

Metode yang diusulkan pada penelitian yang lakukan ini berdasarkan state of the art tentang analisa prediktif curah hujan menggunakan teknik data mining data rentet waktu (time series) dengan menggunakan pendekatan Neural Network (NN) untuk menghasilkan konfiguasi / model algoritma Neural Network yang terbaik.

\section{METODE PENELITIAN}

Penelitian ini dilakukan di Kota Makassar dengan sumber data dari BMKG Romang Polong, tipe data dalam penelitian ini, yakni data primer dan data sekeunder, dengan pengolahan data toolls Rapid Minner.

Adapun gambaran langkah-langkah dapat dilihat pada gambar di bawah ini:

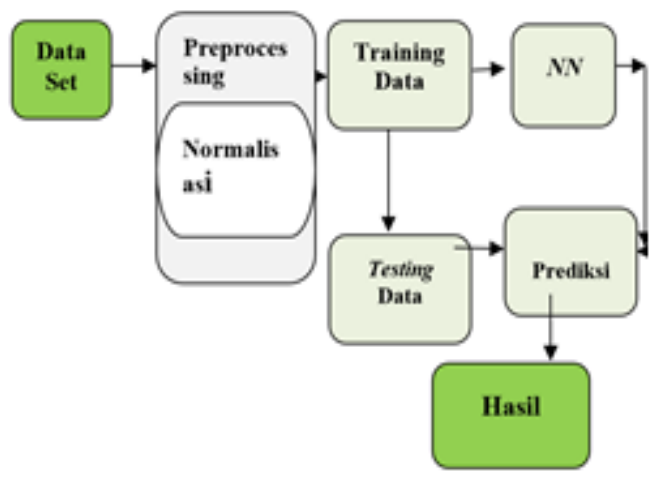

Gambar 1 Model yang diusulkan

\section{HASIL DAN PEMBAHASAN}

4.1 Proses Awal (Preprocessing)

Proses awal yang dilakukan sebelum dilakukannya proses pengujian metode yang diusulkan yaitu Neural Network dan Particle Swarm optimization adalah Preprocessing, pada penelitian ini preprocessing adalah normalisasi data, dengan menggunakan persamaan pada rumus di bawah ini, yaitu:

NewData $=$ (data-Min) $x($ Newmax-Newmin $)$

(Max-Min)+Newmin

$$
\text { NewData }=\frac{(682-0) x(1-0)}{(1235)+0}
$$

$$
\text { NewData }=\frac{682}{1235} \quad=0,552227
$$

Keterangan :

682 :Data awal

1235 : Data terbesar

$0 \quad$ : Data terendah

0,552227 : Hasil normalisasi

Dengan menggunakan persamaan di atas maka dihasilkan normalisasi data seperti pada tabel 1 di bawah ini:

Tabel 1. Hasil Normalisasi Data Curah Hujan

\begin{tabular}{cccc}
\hline Thn & bln & $\begin{array}{c}\text { Curah } \\
\text { hujan } \\
(\mathbf{m m})\end{array}$ & $\begin{array}{l}\text { Normalisasi } \\
\text { Data }\end{array}$ \\
\hline 2006 & Jan & 682 & 0,552227 \\
& Feb & 633 & 0,512551 \\
& Mar & 363 & 0,293927 \\
& Apr & 359 & 0,290688 \\
Mei & 131 & 0,106073 \\
& Jun & 125 & 0,101215 \\
& Jul & 0 & 0 \\
Agu & & 0 \\
& Sep & & 0 \\
Okt & & 0 \\
Nov & 29 & 0,023482 \\
Des & 579 & 0,468826 \\
2015 & Jan & $\ldots$ & 0,697976 \\
& $\ldots$ & $\ldots$ & $\ldots$ \\
Des & 622 & 0,503644 \\
\hline
\end{tabular}


Tabel 1 merupakan hasil pengubahan data univariate dalam bentuk bulanan yang proses selanjutnya pengubahan data univariate ascending ke univariate descending dan kemudian dinormalisasi. Tahap proses selanjutnya adalah mengubah data univariate ke multivariate, mulai dari variabel input atau variabel atribut 1 sampai dengan 50 variabel, sebagai sampelnya dapat di lihat dari tabeltabel berikut:

Tabel 2. Data Multivariate 5 Atribut

\begin{tabular}{|c|c|c|c|c|c|}
\hline $\mathrm{xm}-5$ & ... & xm-3 & xm-2 & xm-1 & $\mathbf{X m}$ \\
\hline 0,101215 & $\ldots$ & 0,290688 & 0,293927 & 0,512551 & 0,552227 \\
\hline 0 & & 0,106073 & 0,290688 & 0,293927 & 0,512551 \\
\hline 0 & & 0,101215 & 0,106073 & 0,290688 & 0,293927 \\
\hline$\ldots$ & & ... & $\ldots$ & ... & . \\
\hline 0 & & 0 & 0 & 0,052632 & 0,05749 \\
\hline 0,090688 & & 0 & 0 & 0 & 0,052632 \\
\hline 0,503644 & $\ldots$ & 0 & 0 & 0 & 0 \\
\hline
\end{tabular}

Tabel 2 adalah tabel multivariate data curah hujan 5 atribut dan memiliki variabel $x m-5, x m-4, x m-3, x m-2, x m-1$ yang merupakan variabel independent serta $x m$ sebagai variabel dependent.
Adapun tabel multivariate data curah hujan ini penulis olah sampai dengan Atribut variabel XM-50.

Tabel 3. Data Multivariate 50 Atribut

\begin{tabular}{cccccc}
\hline $\mathbf{x m - 5 0}$ & $\ldots$ & $\mathbf{x m - 3}$ & $\mathbf{x m - 2}$ & $\mathbf{x m - 1}$ & $\mathbf{x m}$ \\
\hline 0,2583 & $\ldots$ & 0,290688 & 0,293927 & 0,512551 & 0,552227 \\
0,230769 & $\ldots$ & 0,106073 & 0,290688 & 0,293927 & 0,512551 \\
0,180567 & $\ldots$ & 0,101215 & 0,106073 & 0,290688 & 0,293927 \\
$\ldots$ & $\ldots$ & $\ldots$ & $\ldots$ & $\ldots$ & $\ldots$ \\
0 & & 0.088259 & 0 & 0.001619 & 0.003239 \\
0 & & 0.157085 & 0.088259 & 0 & 0.001619 \\
0.090688 & & 0.580567 & 0.157085 & 0.088259 & 0 \\
0,503644 & & & 0,580567 & 0,157085 & 0,088259 \\
\hline
\end{tabular}


Tabel diatas adalah data multivariate 50 atribut dan memiliki variabel XM-50, ..., $X m-9, x m-8, x m-7, x m-6, x m-5, x m-4, x m-$ 3, $x m-2, x m-1$ yang merupakan variabel independent serta $x m$ sebagai variabel dependent.

Berdasarkan format data pelatihan pada tabel 3 diperoleh model yang terbaik menggunakan Input Layer 30, dengan 17 Hidden Layer, Training Cycle 500, Learning Rate, 0,3 dan Momentum 0,2. Adapun Model Arsitektur jaringan Neural Network dapat dilihat pada gambar 2.

4.2 Proses Ekperiment Menggunakan Neural Network

Data pelatihan dilakukan dengan memberikan nilai pada lapisan neuran

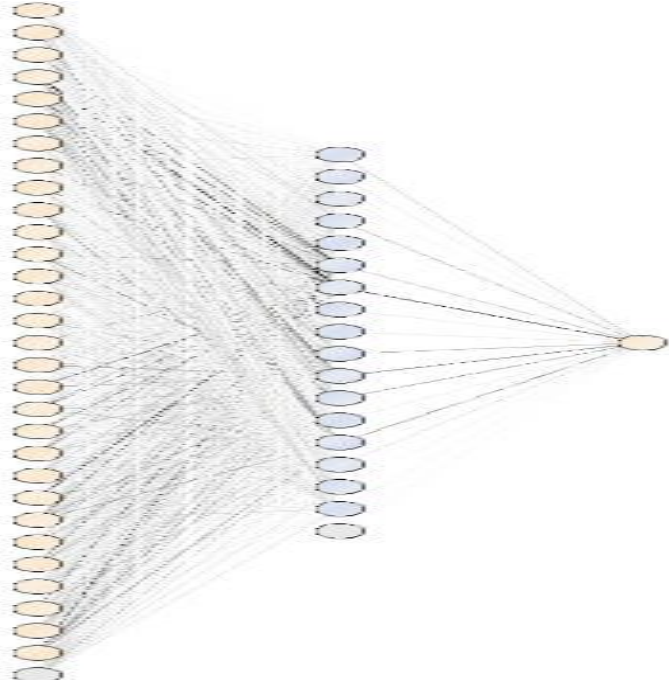

Gambar 2. Model Arsitektur Neural Network

input layer yang diperoleh dari hasil normalisasi yang sudah dilakukan, kemudian menentukan bobot awal dan bias secara acak antara input layer dan hidden layer atau disebut dengan jaringan (vij).

Tabel 4 Bobot Awal dan Bias pada Jaringan $\left(\mathrm{V}_{\mathrm{iJ}}\right)$

\begin{tabular}{|c|c|c|c|c|c|c|}
\hline \multirow{2}{*}{$\begin{array}{l}\text { Hidden } \\
\text { Layer }\end{array}$} & \multicolumn{5}{|c|}{ Input layer } & \multirow[t]{2}{*}{ Bias } \\
\hline & $\mathrm{xm} 1$ & $\mathrm{xm} 2$ & $\mathrm{xm} 3$ & $\ldots$ & $\mathrm{xm} 30$ & \\
\hline zd1 & $-0,036$ & 0,193 & 0,096 & & 0,02 & $-0,166$ \\
\hline $\mathrm{zd} 2$ & $-0,070$ & 0,153 & 0,121 & & 0,018 & $-0,153$ \\
\hline $\mathrm{zd} 3$ & $-0,098$ & $-0,016$ & 0,080 & $\cdots$ & 0,026 & $-0,219$ \\
\hline $\begin{array}{c}\ldots \\
\mathrm{zd} 17\end{array}$ & $\begin{array}{r}\cdots \\
0,272\end{array}$ & $\begin{array}{r}\cdots \\
-0,043\end{array}$ & $\begin{array}{r}\cdots \\
0,041\end{array}$ & $\begin{array}{l}\cdots \\
\ldots\end{array}$ & $\begin{array}{r}\cdots \\
-0,033\end{array}$ & $\begin{array}{r}\cdots \\
-0,155\end{array}$ \\
\hline
\end{tabular}


Dari tabel diatas dapat diketahui bobot awal dan bias secara acak. Setelah ini dilakukan langkah-langkah berikut:

Tahap Perambatan Maju (Forward Propagation)

1. Setiap unit input $(x i, \mathrm{i}=1,2,3, \ldots, \mathrm{n})$ menerima sinyal $x i$ dan meneruskan sinyal tersebut ke semua unit pada lapisan tersembunyi.

2. Pada tahap ini lapisan hidden layer $(\mathrm{Zj})$ menjumlahkan sinyal-sinyal yang dikirim dari input layer ( $X \mathbf{i})$ atau disebut dengan jaringan (vij) yang sudah diberi bobot menggunakan rumus persamaan pada contoh di bawah ini:

$\mathrm{Z} \_\mathrm{in} \mathrm{n}_{\mathrm{j}}=\mathrm{b} 1_{\mathrm{j}}+\sum_{i=1}^{n} \mathrm{x}_{\mathrm{i}}$.

Persamaan di atas dapat diaplikasikan seperti di bawah ini:

$$
\begin{aligned}
& \mathrm{z}_{-} \text {in }_{1}=\mathrm{xm}_{1} * \mathrm{v}_{1.1}+\mathrm{xm}_{2}{ }^{*} \mathrm{v}_{2.1}+\mathrm{xm}_{3} * \mathrm{v}_{3.1}+ \\
& \mathrm{xm}_{4}{ }^{*} \mathrm{v}_{4.1} \ldots+\mathrm{xm}_{30} * \mathrm{v}_{30.1}+1 * \mathrm{vb}_{.1} \\
& =0,51255^{*}-0,036 \\
& 0,293688 * 0,193 * 1+0,290688 * 0,096 * 1+ \\
& 0,106073 * 0,115^{*} 1+0,101215 * 0,074 * 1+ \\
& 0 * 0,058 * 1+0 * 0,229 * 1+0 * 0,064 * 1+ \\
& 0 * 0.052 * 1+0,023484 * 0,126 * 1+ \\
& 0,468826^{*}-0,017 * 1+0,528745^{*}-0,222+ \\
& 0,508502 * 0,125 * 1+0,180567 * 0,045 * 1 \\
& +\ldots 0,018623 * 0.02 *-0,166 \\
& \text { Hasil }=0,000697 \ldots \\
& \mathrm{Z}-\mathrm{in}_{17}=\mathrm{xm} 1 * \mathrm{~V} 1.2+\mathrm{xm} 2 * \mathrm{v} 2.2 .1+\mathrm{xm} 3 * \\
& \text { v3.3... }+x m 30 * v 30.30+1 * v b .17
\end{aligned}
$$

\begin{tabular}{|c|c|}
\hline Hidden Layer & Hasil \\
\hline z_in 1 & 0,0007 \\
\hline z_in 2 & 0,18213 \\
\hline z_in 3 & 0,29648 \\
\hline z_in 4 & 0,17806 \\
\hline z_in 5 & 0,36399 \\
\hline z_in 6 & $-1,02$ \\
\hline z_in 7 & 1,3557 \\
\hline z_in 8 & 0,38063 \\
\hline z_in 9 & $-0,1874$ \\
\hline z_in 10 & 1,08011 \\
\hline z_in 11 & 0,14301 \\
\hline z_in 12 & $-0,651$ \\
\hline z_in 13 & 0,05329 \\
\hline z_in 14 & 0,40039 \\
\hline z_in 15 & $-0,7243$ \\
\hline z_in 16 & 0,42634 \\
\hline z_in 17 & 0,80602 \\
\hline
\end{tabular}

Hasil $=0,182132794$
Tabel 5. Jaringan $\left(\mathrm{V}_{\mathrm{ij}}\right)$ secara keseluruhan

Kemudian menghitung fungsi aktivasi pada sinyal keluaran pada Hidden Layer menggunakan persamaan di bawah ini:

$$
\mathrm{z}_{\mathrm{j}}=f\left(\mathrm{z}_{-} \mathrm{in}_{\mathrm{j}}\right)=\frac{1}{1+e^{-e n j}}
$$

Diaplikasikan seperti di bawah ini

$$
\begin{aligned}
& z d 1=f\left(z \_i n_{1}\right)=\frac{1}{1+e^{-z_{-} \mathrm{in}_{1}}} \\
& =1 /\left(1+\mathrm{EXP}\left(* 0,000697 *^{-} 1\right)\right) \\
& \text { Hasil }=0,50017 \\
& z d 2=f\left(z_{-} \text {in }_{2}\right)=\frac{1}{1+e^{-z_{-} \mathrm{in}_{2}}} \\
& =1 /(1+\operatorname{EXP}(* 0,1821 *-1)) \\
& \text { Hasil } \quad=0,5454
\end{aligned}
$$


Dalam tabel 6 (enam) berikut memperlihatkan keseluruhan dari daftar nilai hasil aktivasi pada Hidden layar dari fungsi aktivasi $\mathrm{Zd} 1$ sampai dengan $\mathrm{Zd} 17$ Tabel 6 Fungsi Aktivasi pada Hidden layer

\begin{tabular}{ccccc}
\hline No & Fugsi Aktivasi & $\mathrm{z}_{-} \mathrm{in}$ & $\mathrm{e}^{-z_{-} \mathrm{in}_{\mathrm{j}}}$ & Hasil \\
\hline 1 & $\mathrm{zd}_{1}$ & 0,0137 & 0,9864 & 0,50017 \\
2 & $\mathrm{zd}_{2}$ & 0,18213 & 0,83349 & 0,54541 \\
3 & $\mathrm{zd}_{3}$ & 0,29648 & 0,74343 & 0,57358 \\
4 & $\mathrm{zd}_{4}$ & 0,17806 & 0,8369 & 0,5444 \\
$\ldots$ & $\ldots$ & $\ldots \ldots$ & $\ldots$ & $\ldots$ \\
17 & $\mathrm{zd}_{17}$ & 0,80602 & 0,44663 & 0,69126 \\
\hline
\end{tabular}

Output Layer atau yang biasa disebut 3. Langkah selanjutnya adalah dengan jaringan $\left(w_{j k}\right)$, seperti pada tabel 7 memberikan nilai bobot dan bias secara di bawah ini: disajikan dalam bentuk tabel sebagai berikut. acak antara jaringan Hidden Layer dan

Tabel 7 bobot Awal dan Bias Jaringan $\left(w_{j k}\right)$

\begin{tabular}{|c|c|c|c|c|}
\hline \multicolumn{2}{|c|}{ Hidden Layer } & \multicolumn{2}{|c|}{$\begin{array}{c}\text { Output } \\
(Y)\end{array}$} & \multirow[t]{2}{*}{$\mathrm{Zd}_{\mathrm{j}}^{*} \mathrm{Y}$} \\
\hline Index & Nilai & Index & nil & \\
\hline $\mathrm{Zd}_{1}$ & 0,000697166 & $\mathrm{~W}_{1.1}$ & 0,308 & 0,1540537 \\
\hline $\mathrm{Zd}_{2}$ & 0,545407744 & $\mathrm{w}_{2.1}$ & 0,237 & 0,129261635 \\
\hline $\mathrm{Zd}_{3}$ & 0,573581244 & $\mathrm{w}_{3.1}$ & $-0,029$ & $-0,01663386$ \\
\hline $\mathrm{Zd}_{4}$ & 0,544396734 & $\mathrm{~W}_{4.1}$ & 0,125 & 0,068049592 \\
\hline ... & $\ldots$ & $\ldots$ & $\ldots$ & $\ldots$ \\
\hline $\mathrm{Zd}_{17}$ & 0,691261486 & W17.1 & $-0,432$ & $-0,29862496$ \\
\hline
\end{tabular}

Pada tahap ini lapisan Output Layer menjumlahkan sinyal-sinyal input yang sudah diberi bobot dari jaringan Hidden Layer menuju Output Layer atau yang biasa disebut dengan jaringan $\left(w_{j k}\right)$ dengan menggunakan rumus persamaan pada contoh berikut ini:

$$
\begin{aligned}
& y_{-} \mathrm{in}_{\mathrm{k}}=\mathrm{b} 22_{\mathrm{k}}+\sum_{j=i}^{p} \mathrm{z}_{\mathrm{j}} . \\
& \mathrm{w}_{\mathrm{jk} \ldots \ldots \ldots \ldots \ldots \ldots \ldots \ldots \ldots \ldots \ldots \ldots \ldots \ldots}(4) \\
& \text { Hasilnya }=0,351243
\end{aligned}
$$

4. Kemudian menghitung fungsi aktivasi pada sinyal keluaran pada Output Layer menggunakan persamaan di berikut ini: 


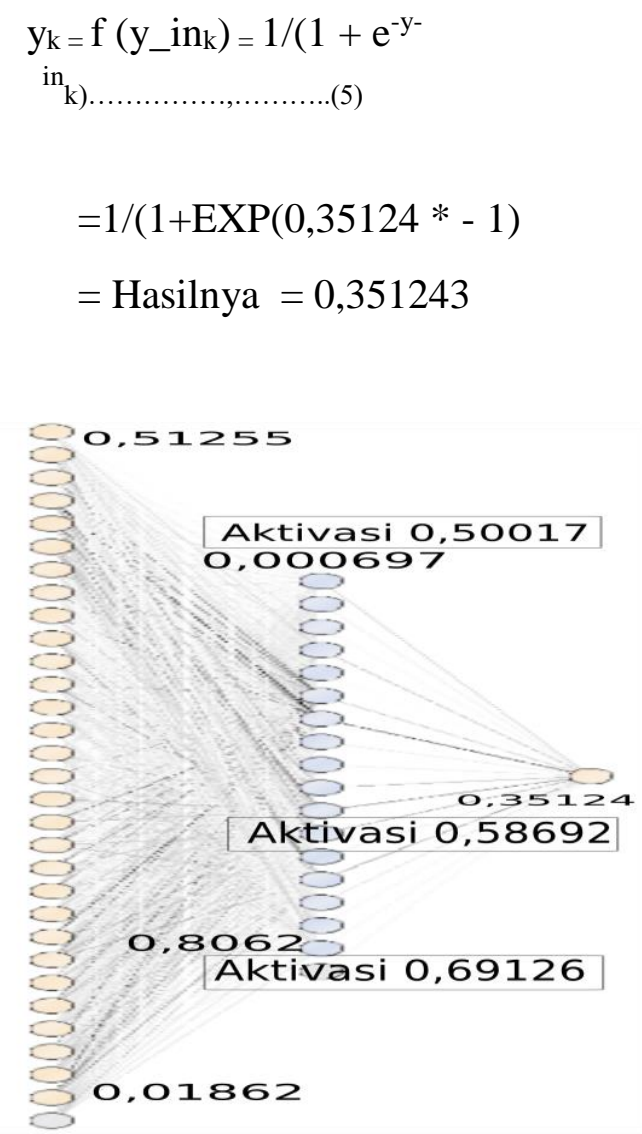

Gambar 3 Nilai keluaran dan aktivasi pada hidden layer dan output

Tahap Perambatan Balik

$$
\begin{aligned}
& \delta_{k}\left(t_{k}-y_{k}\right) f^{\prime}\left(y_{-} i n_{k}\right)=\left(t_{k}-y_{k}\right) y_{k}(1- \\
&\left.y_{k}\right) \ldots \ldots(6) \\
& \delta_{\mathrm{k}}=\left(\operatorname{xd}-y_{k}\right) * y_{k} *\left(1-y_{k}\right) \\
&=(0,552227-0,58692) * 0,58692 \\
& \\
& \quad(1-0,58692) \\
&=-0,00841
\end{aligned}
$$

Kemudian langkah selanjutnya adalah menghitung koreksi bobot (yang nantinya akan digunakan untuk memperbaiki nilai pada jaringan $w_{j k}$ ) dengan menggunakan rumus persamaan di bawah ini:

$$
\begin{aligned}
& \Delta w_{1.1}=\alpha * \delta_{k} * Z j_{1} \\
& \quad=0,3 * 0,00841 * 0,50017 \\
& =-0,00126
\end{aligned}
$$

$$
\begin{aligned}
& \Delta w_{1.17}=\alpha * \delta_{k} * Z j j_{17} \\
& =0,3 *-0,00841 * 0,69126 \\
& =-0,00174
\end{aligned}
$$

Dan menghitung koreksi bias dengan persamaan berikut:

$\Delta \mathrm{w}_{\mathrm{j} k}=$<smiles>[Mg][Mg]</smiles>

Persamaan di atas dapat diaplikasikan seperti di bawah ini:

$$
\begin{array}{ll}
\Delta \mathrm{w}_{\mathrm{b} .1} & =* \delta \mathrm{k} \\
& =0,3 *_{-}-0,00841 \\
\text { Hasil } & =-0,0025
\end{array}
$$

Tahap berikut tiap-tiap unit tersembunyi yaitu Hidden Layer menjumlahkan delta inputanya

$$
\delta_{-} i n_{j}=\sum_{k=1}^{m} \delta_{\mathrm{k}} \cdot \mathrm{w}_{\mathrm{jk}}
$$

Dari tabel 4. menunjukkan daftar Hasil Hidden Layer dan delta inputannya. Selanjutnya kalikan informasi error nilai turunan dari fungsi aktivasinya menggunakan rumus di bawah ini:

$$
\delta_{j}=\delta \_i n_{j .} f^{\prime}\left(z_{-} i n_{j}\right)=\delta \_i n_{j .} Z_{j} .\left(1-z_{j}\right) \ldots .(9)
$$

Diaplikasikan seperti contoh berikut :

$$
\begin{aligned}
\delta_{\mathrm{j} .1} & =\delta \_i n_{1} * Z_{j 1} *\left(1-Z_{j 1}\right) \\
& =-0,0026 * 0,50017 *(1-0,50017) \\
& =-0,00000180
\end{aligned}
$$

Langkah berikut menghitung koreksi bobot yang nantinya akan digunakan untuk memperbaiki nilai jaringan $(w)$ menggunakan persamaan rumus di bawah ini:

$$
\Delta v_{i j}=\alpha * \delta_{j} * x_{i} \quad ; \quad \Delta v_{i j}=\alpha * \delta_{j}(\text { bias })
$$


Persamaan di atas diaplikasikan seperti di bawah ini:

$$
\begin{array}{ll}
\Delta v_{1.1} & =\alpha * \delta_{j .1} * x m_{1} \\
& =0,3 *-0,0006476 * 0,51255 \\
\text { Hasil } & =-0,0000996 \\
\ldots & \\
\Delta v_{1.17}=\alpha * \delta_{j .17} & * x m_{17} \\
& =0,3 *-0,0007755 * 0,1862 \\
\text { Hasil } \quad & =-0,0000043
\end{array}
$$

Tahap Perubahan Bobot Dan Bias

1. Langkah selanjutnya output layer memperbaiki nilai bobot dan bias menggunakan persamaan di bawah ini:

$$
w_{j k}(\text { baru })=w_{j k(l a m a)}+\Delta w_{j k \ldots}
$$

diaplikasikan seperti di bawah ini:

$$
\begin{aligned}
& w_{1.1}=w_{1.1(\text { lama })}+\Delta w_{1.1} \\
& =0,308+-0,00128 \\
& =0,306721
\end{aligned}
$$

Selanjutnya Hidden Layer memperbaiki nilai bobot dan bias menggunakan persamaan di bawah ini:

$v_{i j}($ baru $)=v_{i j(\text { lama })}+\Delta v_{i j}$ ...(12)

2. Selanjutnya adalah melakukan evaluasi setelah 1 iterasi diselesaikan, dengan menghitung Root Mean Square Error (RMSE) dan apabila nilai yang dihasilkan (RMSE) masih besar maka dilanjutkan dengan iterasi-2 sampai iterasi ke-n. Berikut ini rumus untuk menghitung nilai Mean Square Error (MSE)

$\mathrm{MSE}=\frac{1}{30} \sum\left(Y_{t}-Y_{t}^{\prime}\right)^{2}$
Selanjutnya nilai RMSE adalah :

$$
\begin{aligned}
\mathrm{RMSE} & =\sqrt{M S E} \\
& =\sqrt{0,01367} \\
& =0,117
\end{aligned}
$$

Koreksi bias jaringan $\Delta v_{i j}$

Penentuan Parameter Neural Network

1. Penentuan input

2. Pada proses tahapan ini telah dilakukan eksperimen uji coba untuk mendapatkan model yang terbaik pada data 1 periode sampai dengan 50 variabel dengan pengujian pada training cycle 500, 600, 800, 900, 1000, 1100, 1200,1300, 1400, 1500, dengan learning rate 0,3 dan momentum 0,2 .

3. Penentuan Learning Rate

4. Penentuan Hidden Layer

5. Penentuan Momentum

\subsection{Evaluasi Neural Network}

Hasil dari percobaan yang telah dilakukan diperoleh model terbaik dari Neural Network yaitu input layer 30, hidden layer 17, training cycle 500, learning rate 0,1 dan momentum 0,2 setelah proses iterasi ke 500 maka diperoleh nilai RMSE terkecil seperti pada Nilai RMSE Berikut:

Root Mean Squared Error 0.126-0,027 (mikro:0,129+/- 0,000).

Sehingga prediksi curah hujan dari melihat RMSE yang dihasilkan relatif nilai errornya kecil sehingga NN mampu di pergunakan sebagai salah satu metode dalam prediksi.

$$
=0,01367
$$




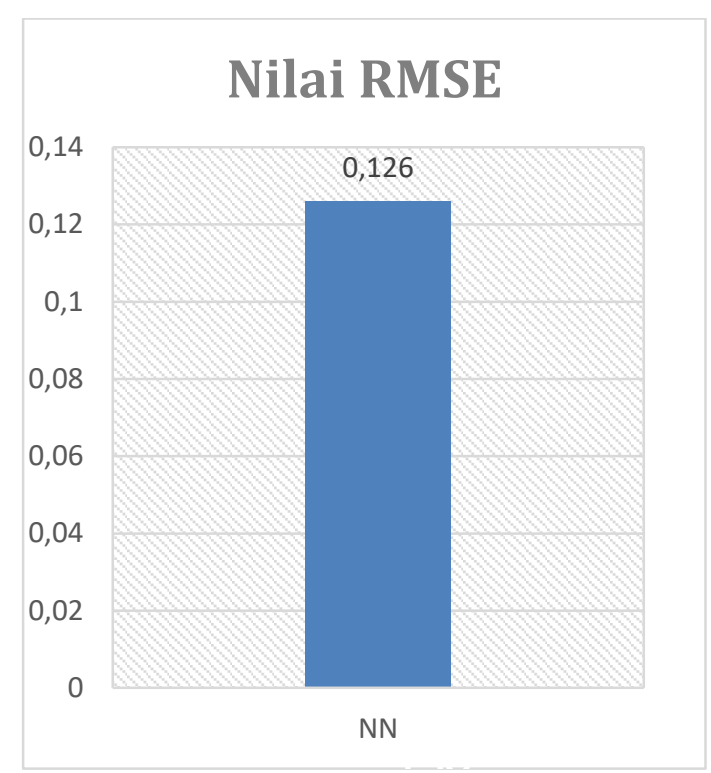

Gambar 4 Nilai RMSE Metode NN

\section{SIMPULAN DAN SARAN}

Hasil dari experiment yang sudah dilakukan pada penelitian ini dapat disimpulkan bahwa hasil evaluasi yang sudah dilakukan menggunakan metode Neural Network (NN) tool rafid minner mampu memberikan nilai Root Mean Square Error yang lebih rendah dalam melakukan prediksi Curah Hujan sebesar $0,216 \%$, dengan hasil dari percobaan yang telah dilakukan diperoleh model terbaik dari Neural Network yaitu input layer 30, hidden layer 17, training cycle 500, learninssil rate 0,1 dan momentum 0,2 setelah proses iterasi ke 500 yang sudah di lakukan membuktikan bahwa Neural Nework mampu memberikan hasil yang lebih rendah didalam melakukan prediksi curah hujan data time series.

Berdasarkan hasil pengujian dan kesimpulan yang penulis paparkan, maka penulis menyarankan :

1. Untuk mengetahui kemampuan Neural Network (NN) didalam meningkatkan kinerja Jaringan Syaraf Tiruan didalam menghasilkan nilai Root Mean Square
Error yang lebih rendah diperlukan metode lain sebagai pembanding.

2. Pada penelitian selanjutnya dengan menggunakan data yang sama, sebaiknya menggunakan pendekatan teknologi komputasi yang lebih cerdas agar mendapatkan hasil prediksi atau model terbaik untuk prediksi curah hujan.

3. Penelitian yang telah dilakukan, sebaiknya langsung diimplementasikan terhadap kehidupan nyata, khususnya dalam peramalan prediksi curah hujan sehingga dapat membantu petani dalam penentuan pola tanam.

\section{UCAPAN TERIMA KASIH}

Terima kasih Penulis ucapkan kepada RISTEK DIKTI yang telah memberikan dana penulisan jurnal.

\section{DAFTAR PUSTAKA}

Gema Indah Merdekawati , Idmail," Prediksi Curah Hujan Di Jakarta Berbasis Algoritma Levenberg Marquardt," Jurnal Ilmiah Informatika Komputer Volume 24 No..2 Agustus 2019.

Y.H. Zweiri, J.F. Whidborne dan L.D. Sceviratne, "A three-term backpropagaion algorithm," Neurocomputing, vol, 50, pp, 305318,2003 .

Pritpal Singh dalam Applications of Soft Computing in Time SeriesForecasting, Series editor Janusz Kacprzyk, 2015

Mehdi Mahnam dan Ghomi, "Time Variant Fuzzy Time Series Approach For Forecasting Using Particle Swarm Optimization". International Journal Of Industrial Engineering dan Production Research 23, 2012. 
Ikke Fitriyaningsih, Yuniarti Basani,Let

Malem Ginting, "Web-Based Application Development For Predicting Rainfall, Water Discharge, And Flood using Machine Learning Method In Deli Serdang ," jurnal Penelitian Komunikasi dan Opini Publik Vol.22,143-155, 13-12-2018.

Alven Safik Ritonga, "Prediksi Curah Hujan Menggunakan Jaringan Syaraf Tiruan Fugsi Basis Radial Untuk Mendukung Manajemen Pola Tanam," Institut Teknologi Surabaya, Tesis-SM142501, 2015.

Defanto Hanif Yoranda, dkk," Prediksi Intensitas Curah Hujan Menggunakan Metode Jaringan Saraf Tiruan Backpropagation,'JPTIIK,Pebruari 2018.

Muis Nanja, Purwanto, "Metode KNearest Neighbor Berbasis Forward Selection untuk Prediksi Harga Komoditi Lada" Jurnal Pseudocode, Volume 2 Nomor 1, Februari 2015.

I.M.Sofian dan Y.Apriani," Metode Peramalan Jaringan Saraf Tiruan Menggunakan Algoritma Backpropagation (Studi Kasus Peramalan Curah Hujan Kota Palembang)," Jurnal MIPA Universitas Sriwijaya, 1 Oktober 2017.

Nurul Hidayat, I Wayan Sudiarta dan Marzuki,"Rainfall Forecast In The City Of Mataram In The Year 2015 And 2016 Using Time Delay Neural Network Method,'Jurnal KUANTA, VOl.1.No.1. April 2015.

Syaefuddin Suhaedi, dkk,"ANN Back Propagation For Forecasting and Simulation Hydroclimatology Data," Prosiding Seminar Nasional
Pendidik dan Pengembang Pendidikan Indonesia, 2017.

Marihot TP.Manalu," Jaringan Syaraf Tiruan Untuk Memprediksi Curah Hujan Sumatera Utara dengan Metode Backpropagation (Studi Kasus: BMKG Medan)." JURIKOM, Volume:3, Nomor: 1, Februari 2016.

Ulviyana Cahyati,'Prediksi Curah Hujan Dengan Menggunakan Metode Jaringan Syaraf Tiruan (JST) Backpropagation sebagai Pendukung Kalender Tanam Di Kabupaten Lamongan,'Universitas Islam Negeri Sunan Ampel Surabaya,2019.

Nola Ritha, Martaleli Bettiza, Ariel Dufan," Prediksi Curah Hujan Dengan Menggunakan Algoritma Levenberg -Marquardt dan Backpropagation," Jurnal Sustainable, Vol.5, No.2,Oktober 2016.

Chandra Malvin, Sovia Rini, and Permana Randy, "Analisis Metode Backpropagation Untuk Memprediksi Indeks Harga Saham Indofood Sukses Makmur TBK.," Jurnal KomTekInfo, Vol. 02, No. 01, Juni 2015.

Utomo Winarto, "Prediksi Nilai Ujian Nasional Produktif Sekolah Menengah Kejuruan Menggunakan Metode Neural Network," Techno.com, Vol. 14, No. 1, pp. 33-41, Februari 2015. 